\title{
ASTEROIDS SEARCH RESULTS IN DIGITIZED OBSERVATIONS OF THE NORTHERN SKY SURVEY PROJECT (KITAB PART)
}

\author{
S.V. Shatokhina ${ }^{1}$, H. Relke ${ }^{2}$, Q.Yuldoshev ${ }^{3}$, V.M. Andruk ${ }^{1}$, Yu. I. Protsyuk ${ }^{4}$, M. Muminov ${ }^{5}$ \\ ${ }^{1}$ Main Astronomical Observatory of National Academy of Sciences, 27 Akad. \\ Zabolotnogo St., 03680, Kyiv, Ukraine,svetash@mao.kiev.ua \\ ${ }^{2}$ Walter Hohmann Observatory, Essen, Germany, helena_relke@yahoo.com \\ ${ }^{3}$ Ulugh Beg Astronomical Institute UAS, Tashkent, Uzbekistan \\ ${ }^{4}$ Research Institute Mykolaiv Astronomical Observatory, Mykolaiv, Ukraine \\ ${ }^{5}$ Andijan State University, Andijan, Uzbekistan
}

\begin{abstract}
Photographic observations of XX century contained numerous and varied information about all objects and events of the Universe fixed on the astronegatives. The original and interesting observations of small bodies of the Solar system in previous years can be selected and used for various scientific tasks. Existing databases and online services can help make such selection easily and quickly.

The observations of chronologically earlier oppositions, photometric evaluation of brightness for long periods of time allow refining the orbits of asteroids and identifying various non-stationarities.

Photographic observations of the Northern Sky Survey project (FON project) were used for global search for small bodies of Solar system. About 2,000 photographic plates of Kitab part of the FON project were made using Double Wide Angle Astrograph at the Kitab observatory (Uzbekistan) during 1981-1989. Early, using that digitized observations the catalogue of equatorial coordinates and stellar magnitudes for more than 13 million stars and galaxies up to $\mathrm{B}=17.5^{\mathrm{m}}$ was compiled. At present, we analyzed all processing results for the search of asteroids and compiled the catalogue of equatorial coordinates and stellar magnitudes of them.
\end{abstract}

As a result more than 4,500 asteroids and comets with visual magnitude from $7^{\mathrm{m}} .7$ to $17^{\mathrm{m}} .5$ were identified now. All positions of asteroids were compared with ephemeris. A preliminary analysis of O-C differences was carried out.

New and interesting are that the moments of official discovery of some identified asteroids much later than their moments of Kitab's observation. In addition, some of them are the earliest observations of these asteroids in the world among all known observations. More than 915 observations of such asteroids have been found on the plates of Kitab part of the FON project.

Keywords: catalogue, asteroids positions, FON project
АБСТРАКТ. Фотографічні спостереження XX століття містять численну та різноманітну інформацію про всі об'єкти та події Всесвіту, зафіксовані на астронегативах. Оригінальні та цікаві спостереження малих тіл Сонячної системи в попередні роки можна вибрати та використовувати для різних наукових завдань. Існуючі бази даних та онлайн-сервіси можуть допомогти зробити такий вибір легко і швидко.

Спостереження хронологічно більш ранніх опозицій, фотометрична оцінка блиску протягом довгих періодів часу дозволяють уточнювати орбіти астероїдів і виявляти різні нестаціонарності.

Фотографічні спостереження Фотографічного огляду північного неба (проект ФОН) були використані для глобального пошуку малих тіл Сонячної системи. Близько 2000 фотографічних платівок Кітабської частини проекту ФОН отримані за допомогою подвійного ширококутного астрографа обсерваторії Кітаб, Узбекистан у період з 1981 по 1989 роки. Спочатку, використовуючи ці оцифровані спостереження, був складений каталог екваторіальних координат і зоряних величин для більш ніж 13 млн зірок і галактик до $\mathrm{B}=17.5^{\mathrm{m}}$. На даний час ми проаналізували усі результати 3 метою пошуку астероїдів та склали каталог їх екваторіальних координат та зоряних величин.

В результаті було ідентифіковано більше 4500 зображень астероїдів і комет із візуальною зоряною величиною від $7^{\mathrm{m}} .7$ до $17^{\mathrm{m}} .5$. Всі положення астероїдів порівнювалися з ефемеридами. Проведено попередній аналіз різниць О-С.

Новим і цікавим $є$ те, що моменти спостереження деяких ідентифікованих астероїдів є значно ранішими, ніж моменти їх відкриття. Крім того, деякі 3 них $\epsilon$ найпершими спостереженнями цих астероїдів у світі серед усіх відомих спостережень. Більше 915 спостережень таких астероїдів були знайдені на платівках Кітабської частини проекту ФОН.

Ключові слова: каталог, положення астероїдів, проект ФОН 


\section{Introduction}

In the implementation of the Photographic Survey of the Northern Sky (the FON project) took part six observatories: Main Astronomical Observatory of Ukraine (Goloseevo), Zvenigorod Observatory of Russia, Hissar Observatory of Tadjikistan, Abastumani Observatory of Georgia, Zelenchuk Observatory of Russia and Kitab Observatory of Uzbekistan. (Pakuliak et al., 2016; Andruk et al., 2017a)

The Kyiv part of the project has been successfully completed. The final result of this part was the catalogue of positions and B-magnitudes for more than 19 million stars and galaxies with $\mathrm{B}<16 .{ }^{\mathrm{m}} 5$ (Andruk et al, 2016b). In addition, a catalogue of 2293 positions of asteroids was compiled based on these observations (Shatokhina et al, 2018).

The Kitab part of the project finished by compilation of the catalogue of equatorial coordinates $\alpha, \delta$, and Bmagnitudes for more than 13 million stars and galaxies up to $\mathrm{B} \leq 17$. $^{\mathrm{m}} 5$ for the epoch 1984.97 (Yuldoshev et al, 2017). Similar to the previous one, now we used the processing results of digitized astronegatives for a global search for small bodies of the Solar system.

The techniques of astroplate digitization and further processing and determination of coordinates and magnitudes of stars are described in the series of publications (Andruk et al., 2014; 2015; 2016a; 2016b; Protsyuk et al., $2014 a ; 2014 b)$. The results of the determination of Solar system bodies positions are described in others one (Kazantseva et al., 2015; Yizhakevych et al., 2014; 2015; 2016; 2017; Protsyuk et al., 2014a; 2014b; Eglitis et al., 2016a; 2016b; Shatokhina et al., 2016; 2017; 2018). Notice, that digitizing of astroplates has been performed using Epson Expression 10000XL commercial scanner, with the resolution 1200 dpi. All scans of plates accumulated in Joint Digital Archive of Ukrainian Virtual Observatory (UkrVO). Standard images were processed using advanced software complex for MIDAS / ROMAFOT programs in LINUX environment. The software was developed and implemented in MAO NASU to process the digitized astronomic negative plates as well as to obtain the final product in the form of a catalogue of positions and stellar magnitudes for all registered objects on the plates.

The equatorial coordinates $\alpha, \delta$ and stellar B-magnitudes of all objects on the plates were obtained in the reference system of Tycho-2 at the epoch of exposition of each plate. The photometry of stars for astroplates was made on the basis of the principles implemented in processing the plates of the FON project (Andruk et al., 2017 b) using photoelectric measurements of stars to construct the characteristic curves of plates (Relke et al., 2015). Photographic B-magnitudes of objects were calibrated with photoelectric standards (Andruk et al., 2016b).

\section{Results}

We analyzed the results of digital processing 1963 photographic plates of the Kitab part of the FON project. Generally, 4529 images of asteroids and 4 images of comets with 8-17.5 magnitudes were found on these plates.
The positions and magnitudes of identified asteroids and comets were compiled into a catalogue.

The quantitative and qualitative characteristics of the received catalog are analyzed. Most of identified asteroids attributed to the Main Belt. Only several of them attributed to the Hilda and Mars crosser families, potentially dangerous and unnumbered ones.

The Fig. 1 shows the distribution on equatorial coordinates RA, DEC of all 4533 identified asteroids for all used plates. Notice, that the plates from Kitab part of the FON project cover the strip on celestial sphere from 0 to 24 hours in right ascention and from $-20^{\circ}$ to $+02^{\circ}$ in declination. For a comparison, the similar distribution of asteroids coordinates identified from Kyiv part observations of the FON project shows on the Fig.1 too.

Analogically the Fig. 2 shows the distribution of visual magnitudes for all identified asteroids for Kitab part and Kyiv part observations. Generally, in comparison with asteroids of the Kyiv part of the project, asteroids of the Kitab part are identified fainter ones up to 17.5 magnitudes. The number of identified Kitabian asteroids is significantly greater compared to asteroids of the Kyiv part of the project. It was achieved by simultaneous exposure of each pair of plates on two telescope tubes in Kitab.

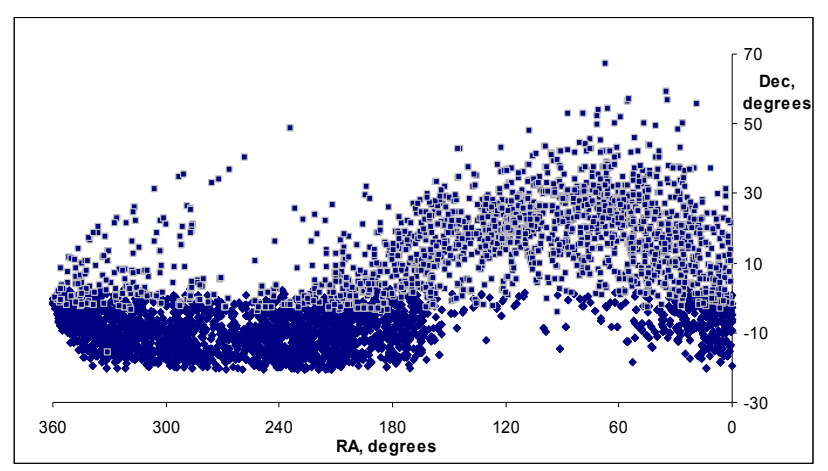

Figure 1: Distribution of coordinates RA, DEC for 4533 identified asteroids of the Kitab part (dark points) and for 2293 asteroids in the Kyiv part (light points) of the FON project.

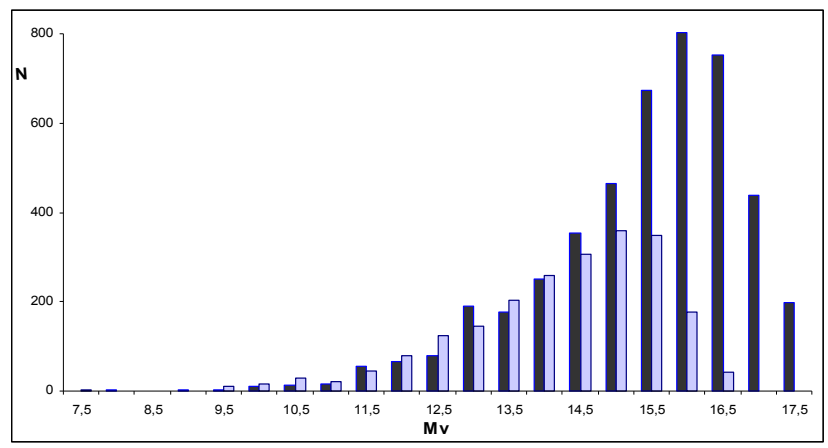

Figure 2: Distribution of visual magnitudes Mv (ephemeris) of asteroids from Kitab part observations (dark bars) and Kyiv part (light bars) of the FON project. 

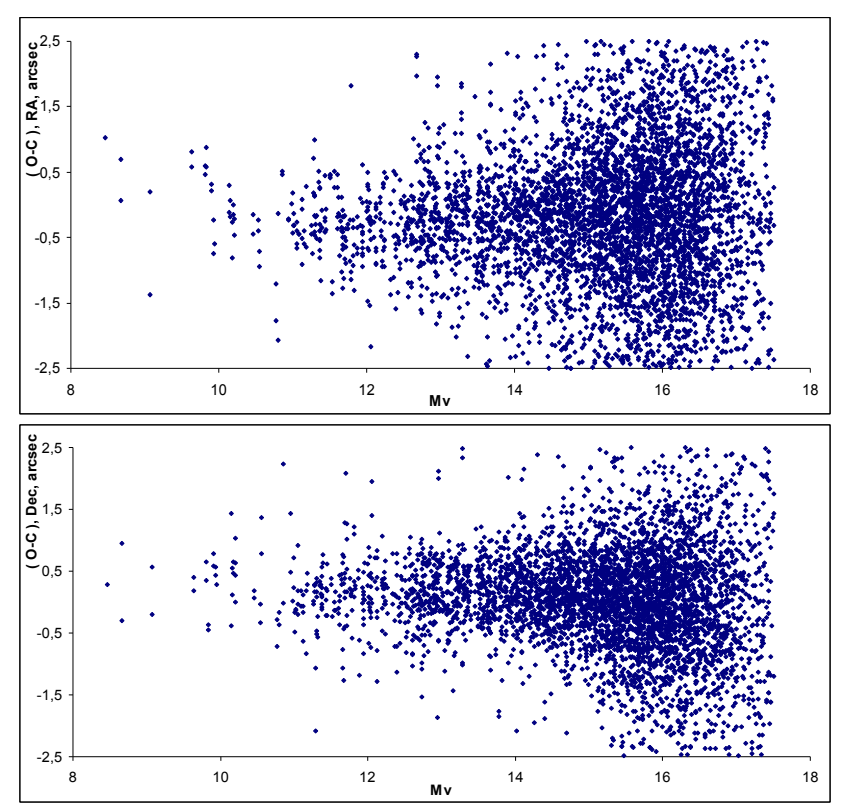

Figure 3: The scatter of individual values $\mathrm{O}-\mathrm{C}$ for all asteroids in coordinate RA (from above) and coordinate DEC (bottom).

All positions of asteroids were compared with the ephemeris JPL DE431 (http://ssd.jpl.nasa.gov/horizons). Identification of asteroids was performed using JPL resources too. The values of $\mathrm{O}-\mathrm{C}$ differences on both coordinates for all asteroids are presented on Fig.3. The scatter of these values is greater in right ascension than in declination for asteroids with different magnitudes. But it increases in both coordinates for asteroids fainter than 15 magnitudes The possible reason for this may be the absence of faint reference stars in Tycho-2 catalogue or small exposures for reliable determination of positions of faint objects.

The brightness of asteroids depends on its geocentric and heliocentric distances and from the angle of phase. In addition, all asteroids exhibit short-period fluctuations in brightness due to their own rotation with periods from several hours to one day, in most cases. Therefore, the obtained stellar B-magnitudes of asteroids contain the results of the influence of all these factors. The amplitude of short-period fluctuations in brightness for different asteroids is different and varies from a few hundredths of a stellar magnitude to two stellar magnitudes. For each asteroid we calculated the difference $\mathrm{B}-\mathrm{Mv}$, where $\mathrm{Mv}$ is the visual magnitude calculated by the ephemeris JPL (taking into account the geocentric and heliocentric distances of the asteroid and the phase angle functions). This difference includes the residual short-period variations in brightness. Fig. 4 presented a scatter of such differences B-Mv for all identified asteroids.

The accuracy of determination of coordinates and B-values of asteroids was investigated for the selected 411 pairs of observations performed on both telescope tubes simultaneously. The standard deviations $\sigma$ from the mean values in both coordinates and the $\mathrm{B}$ values for all positions of asteroids from these pairs of observations are shown in Fig. 5.

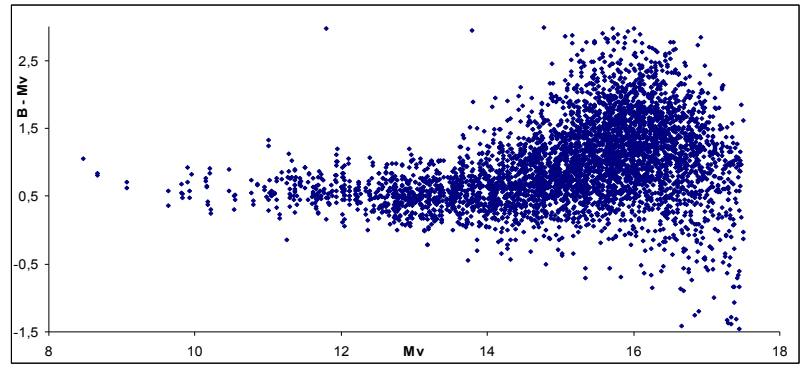

Figure 4: The scatter of differences B-Mv for all asteroids.
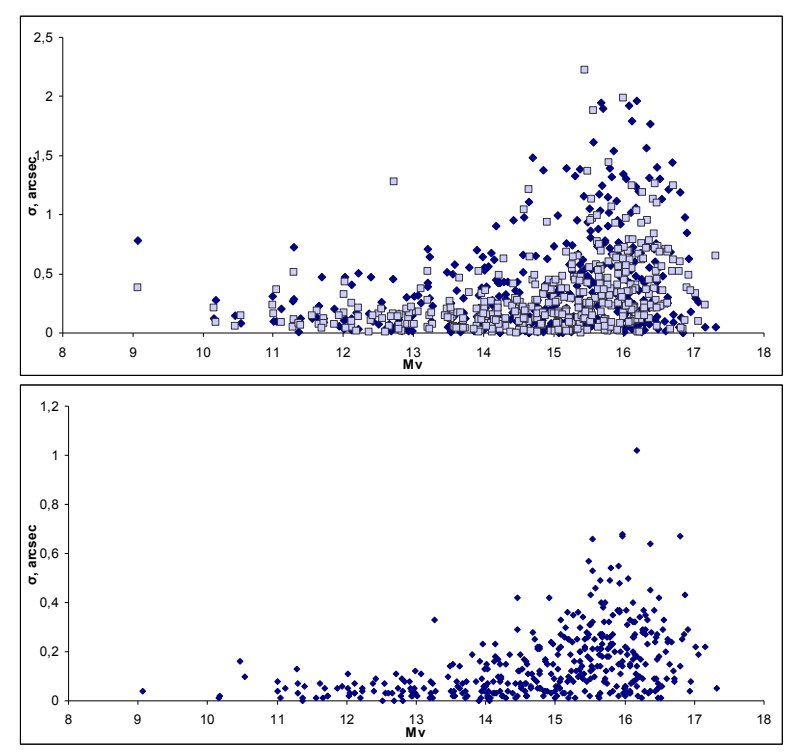

Figure 5: The scatter of values of standard deviations $\sigma$ in coordinates RA (dark points), DEC (light points) (from above) and B-values (bottom) for asteroids of various stellar magnitudes.

From the preliminary analysis of the catalog data, it was found that 915 asteroids positions have moments of observation preceding their discoveries. Besides, these observations from Kitab part of the FON project are the earliest observations of corresponding asteroids in the world among all known observations (according to MPC data (http://www.minorplanetcenter.net/db_search)). As a rule, this is small faint asteroids discovered by CCD and satellites observations from 1990-2005. Most of them belong to such early oppositions of asteroids, which because of the lack of data are not involved in the calculation of ephemerides. Therefore, their differences in $\mathrm{O}-\mathrm{C}$ values can be large. Such asteroids are difficult to identify. Some of these asteroids with O-C less than 2.5 arcsec are included into a present catalog now. Another part of such asteroids with large $\mathrm{O}-\mathrm{C}$ will be included after a critical analysis. The catalog will be presented on UkrVO web-page.

The global search of observations of similar asteroids in the databases of the UkrVO (Vavilova et al., 2012; 2016 ; 2017) followed by the processing of plates, will increase their number. 


\section{Conclusion}

Large photographic sky surveys can become a basis not only for creating a catalogues of stars and galaxies, but also for compiling a catalogue of the positions of small bodies of the Solar System. Digital processing of photographic plates allows to determine with high accuracy the coordinates and stellar magnitudes for all objects.

From observations of Kitab part of the FON project more than 4,500 asteroids and comets with visual magnitudes from $7^{\mathrm{m}} .7$ to $17^{\mathrm{m}} .5$ were compiled into the catalogue. A significant part of asteroids from that catalog belongs to such early oppositions of asteroids, which because of the lack of observational data are not involved in the calculation of ephemerides.

Using data from such catalogues of the positions and magnitudes of asteroids, the following tasks can be solved, such as refining ephemeris, studying changes in asteroid orbits over time, non-gravitational effects in the evolution of asteroid's orbits, constructing asteroid light curves and phase dependencies.

Intensive work on the creation of catalogues of stars and galaxies and small bodies of the Solar System based on digitized observations of Kiev and Kitab parts of the FON project were successfully carried out with the active support of UkrVO.

\section{References}

Andruk V.N., Golovnya V.V., Ivanov G.A. et al.: 2014, Odessa Astron. Publ., 27, N1, 53.

Andruk V.N., Pakuliak L.K., Golovnya V.V. et al.: 2015, arXiv151205535.

Andruk V.M. Golovnia V.V., Ivanov G.A et al.: 2016, Kinem. Phys. Cel. Bodies, 32, N1, 38.

Andruk V.M., Pakuliak L.K., Golovnia V.V. et al.: 2016, Kinem. Phys. Cel. Bodies, 32, N5, 260.

Andruk V., Yuldoshev Q., Eglitis I. et al.: 2017, Odessa Astron. Publ., 30, 159.

Andruk V.M., Pakuliak L.K., Golovnia V.V. et al.: 2017, Scince and Innovation, 13a, 17.
Eglitis I., Eglite M., Andruk V.M. et al.: 2016, Odessa Astron. Publ., 29, 126.

Eglitis I., Eglite M., Andruk V.M.: 2016, Bull. T. Shevchenko Nat.Univ. Kyiv.Astron., 54, 21 (in Ukrainian)

Eglitis I., Eglite M., Shatokhina S.V. et al.: 2016, Odessa Astron. Publ., 29, 123.

Kazantseva L.V., Shatokhina S.V., Protsyuk Yu.I. et al.: 2015, Kinem. Phys. Cel. Bodies, 31, N1, 37.

Pakuliak L., Andruk V., Golovnia V. et al.: 2016, Odessa Astron. Publ., 29, 132.

Protsyuk Yu.I., Andruk V.N., Muminov M.M. et al.: 2014, Odessa Astron. Publ., 27, N1, 61.

Protsyuk Yu.I. Andruk V.N., Kazantseva L.V.: 2014, Odessa Astron. Publ., 27, N1, 59.

Relke E., Protsyuk Yu.I., Andruk V.M.: 2015, Odessa Astron. Publ., 28, 211.

Shatokhina S., Kazantseva L., Kazantsev A.et al.: 2016, Odessa Astron. Publ., 29, 151.

Shatokhina S.V., Andruk V.N., Golovnya V.V.: 2017, Bull. T. Shevchenko Nat.Univ. Kyiv.Astron., 55, 6 (in Ukrainian).

Shatokhina S.V., Kazantseva L.V., Yizhakevych O.M. et al.: 2018, Kinem. Phys. Cel. Bodies, 34, N5, 70.

Vavilova I.B., Pakulyak L.K., Shlyapnikov A.A. et al.: 2012, Kinem. Phys. Cel. Bodies, 28, N4, 85.

Vavilova I.B.: 2016, Odessa Astron. Publ., 29, 109.

Vavilova I.B., Yatskiv Ya.S., Pakuliak L.K.: 2017, IAUS, 325, 361.

Yizhakevych O., Andruk V., Pakuliak L. et al.: 2014, Odessa Astron. Publ., 27, N1, 67.

Yizhakevych O., Andruk V.M., Pakuliak L.K.: 2015, Odessa Astron. Publ., 28, N2.

Yizhakevych O.M., Andruk V.M., Pakuliak L.K.: 2016, Odessa Astron. Publ., 29, 155.

Yizhakevych O. M., Andruk V.M., Pakuliak L.K.: 2017 , Kinem. Phys. Cel. Bodies, 33, N 3, 70.

Yuldoshev Q.X., Ehgamberdiev Sh.A., Muminov M.M. et al.: 2017, Kinem. Phys. Cel. Bodies, 33, N5, 250. 